\title{
A Research on Supplier Performance with Reference to Switching Technologies Gunther Limited
}

\author{
K.Murugan, H.S.Abzal Basha, P.Venkatesh
}

\begin{abstract}
This study is conducted in Switching Technologies Gunther Limited titled “A Study On Supplier Performance” gives various detail about the suppliers who were importing raw materials to the organization to manufacture reed switches. This study explains the factors that commonly influence the performance of the suppliers. Brief information about the industry and company profile is given and also a short description of various research papers related to the study is mentioned to throw light on a few information that helps to conduct the study. The need for education, along with the objectives and scope, is explained. As far as the source of data is concerned with an interview with the executive personnel is used as a primary source and company's records, documents are used as a secondary source of data. The tools such as order cycle lead time, process capability indices, and Pareto analysis has been used. There are few limitations in the study which are mentioned. Detailed information about the data analysis, along with the interpretation, is given to know about the data collected from the organization. The study also provides various suggestions to provide appropriate clearance, increase ordering the materials more frequently, by using management software to automate the transmission of information and optimize the network design. This study draws to a close with the overall conclusion for a better understanding of the study.
\end{abstract}

Key Words: Supplier, software, Organisation.....etc

\section{INTRODUCTION}

SCM is an important aspect of the manufacturing organization. Supply chain management suggests the organization how to deliver the produced product in the proper manner. It is having the chain which starts with the manufacturer and which goes to the wholesaler and after that goes to dealer and which passes through the retailer and finally goes to the customer. This is a very complicated process in the organization which requires lot of effort and proper study which makes the organization better performer. In the present study it's the strength of supply chain

Manuscript published on November 30, 2019.

* Correspondence Author

K.Murugan*, Assistant Professor, Sri Sairam Engineering College, Chennai, Tamilnadu, India.

H.S.Abzal Basha, Assistant Professor, G.Pullaiah College of Engineering \& Technology, Kurnool, AndhraPradesh, India.

P.Venkatesh, Assistant Professor, Sri Sairam Engineering College, Chennai, Tamilnadu, India.

(C) The Authors. Published by Blue Eyes Intelligence Engineering and Sciences Publication (BEIESP). This is an open access article under the CC-BY-NC-ND

license

(http://creativecommons.org/licenses/by-nc-nd/4.0/) management for better productivity and for better control in the organization.

\section{STATEMENT OF PROBLEMS}

$>$ This study is conducted only for three months in the current situation.

$>$ This study is subjected to the regulations of Toxic

substances control act for importing chemicals.

$>$ Topologies, sub-divisions, textures of the importing materials cannot be determined.

$>$ The Constraints of the employees to provide precise details about their importer is limited.

\section{OBJECTIVES OF THE STUDY}

Primary objective:

$>$ To maximize the overall value of the purchaser along with quality products supplied by the supplier.

Secondary objectives:

$>$ To understand how the supplier evaluation accomplished in the organization.

$>$ To learn about strategic supplier relationships with the company.

\section{REVIEW OF LITERATURE}

Martin Mukabi Shiati, Dr. Yusuf Kibet, Dr. Douglas Musiega (2014), stated that supplier selection is the process by which firms identify, evaluate, and contract with suppliers. During the last decades, there has been a growing realization of the vital contribution that suppliers can have on an organization's performance. The questionnaire and the interview schedules were the primary research instruments used in data collection. The researcher then analyzed the data using Statistical Program for Social Scientists (SPSS), where descriptive statistics were generated in terms of frequencies, percentages, and means among others and the results were presented in cross-tabulation and frequency tables.

Kamlesh Nanaji*, Prof. Emeritus M. R. Apte (2015) stated that supplier selection is the purchasing function that forms the foundation for the success or failure of projects. Therefore supplier selection criteria should be well defined. Supplier selection is a multi-criteria decision-making problem that includes both qualitative and quantitative considerations. 
This paper presents a review of supplier selection processes and decision-making methods reported in academic and other literature related to the construction industry.

\section{RESEARCH METHODOLOGY \& RESULTS}

\section{Data Collection}

In the present study, both Primary and Secondary data are used for analysis. The study is classified as analytical in nature.

\section{Tools And Techniques}

Some of the techniques which are used to evaluate supplier performance are as follows,

$>$ Process Capability

$>$ Pareto Analysis

Data Analysis And Interpretation

$\mathrm{Cp}=(\mathrm{USL}-\mathrm{LSL}) / 6 \sigma$

Process Capability Ratio (Cp) for Glass Tubes

Table 1.1

Process Capability of Days

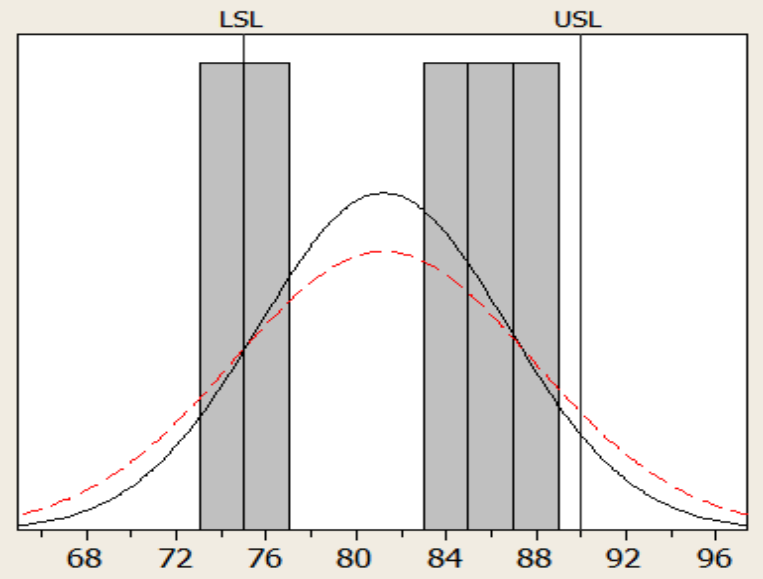

\section{Calculation}

$$
\begin{aligned}
\mathrm{Cp} & =(\mathrm{USL}-\mathrm{LSL}) /(6 * \mathrm{~S} . \mathrm{D}) \\
& =(90-70) /(6 * 4.195) \\
& =0.79
\end{aligned}
$$

\section{Interpretation}

Order Cycle lead Time for entire purchasing process in the year 2012 - 2016 is 73, 86, 87, 84, 76 days and also founded that year 2012 lead time is quietly less than lower specification limit in the process capability.

\section{Process Capability Ratio (Cp) for Nickel iron wires}

It mostly measures some target values and acceptable limits of variation around the target. The upper specification limit is 95 days, and lower specification limit is 75 days. Process capability ratio $\mathrm{Cp}=0.36$.

Table 1.2

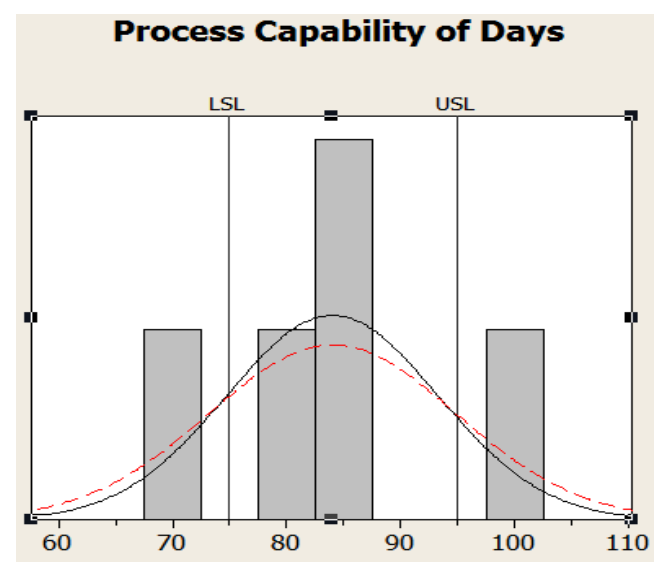

\section{Calculation}

$$
\begin{aligned}
\mathrm{Cp} & =(\mathrm{USL}-\mathrm{LSL}) /(6 * \mathrm{~S} . \mathrm{D}) \\
& =(95-75) /(6 * 6.43) \\
& =0.518
\end{aligned}
$$

\section{Interpretation}

The Order Cycle lead Time for the entire purchasing process in the year 2012 - 2016 is $98,80,85,87,70$ days and also founded that year 2016 lead time is quietly less than lower specification limit and year 2012 has more lead time in the process capability.

\section{Process Capability Ratio (Cp) for chemicals}

It mostly measures some target values and acceptable limits of variation around the target. The upper specification limit is 90 days, and lower specification limit is 70 days. The Process capability ratio is calculated as $\mathrm{Cp}=0.55$.

Table 1.3

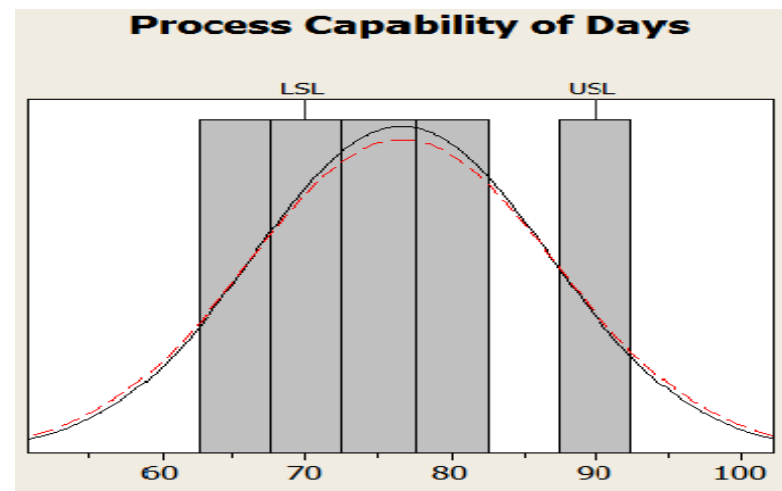

\section{Calculation}

$$
\begin{aligned}
\mathrm{Cp} & =(\mathrm{USL}-\mathrm{LSL}) /(6 * \mathrm{~S} . \mathrm{D}) \\
& =(90-75) /(6 * 4.50) \\
& =0.55
\end{aligned}
$$

\section{Interpretation}

The Order Cycle lead Time for the entire purchasing process in the year 2012 - 2016 is 80, 91, 72, 76, 64 days and also founded that year 2016 lead time is quietly less than lower specification limit and year 2013 has more lead time in the process capability. 


\section{PARETO ANALYSIS METHOD}

Pareto Analysis for Glass tubes

Table 1.4

\begin{tabular}{|l|l|l|l|}
\hline Year & Received Quantity & Accepted \% & Accepted Quantity \\
\hline 2012 & 12024950 & 0.99971 & 12021462.76 \\
\hline & & & \\
2013 & 7764810 & 0.99963 & 7761937.02 \\
\hline & & & \\
2014 & 9985260 & 0.99965 & 9981765.16 \\
\hline 2015 & 14060930 & & \\
\hline & & 0.99974 & 14057274.16 \\
\hline 2016 & 9970930 & & \\
\hline
\end{tabular}

Table 1.5

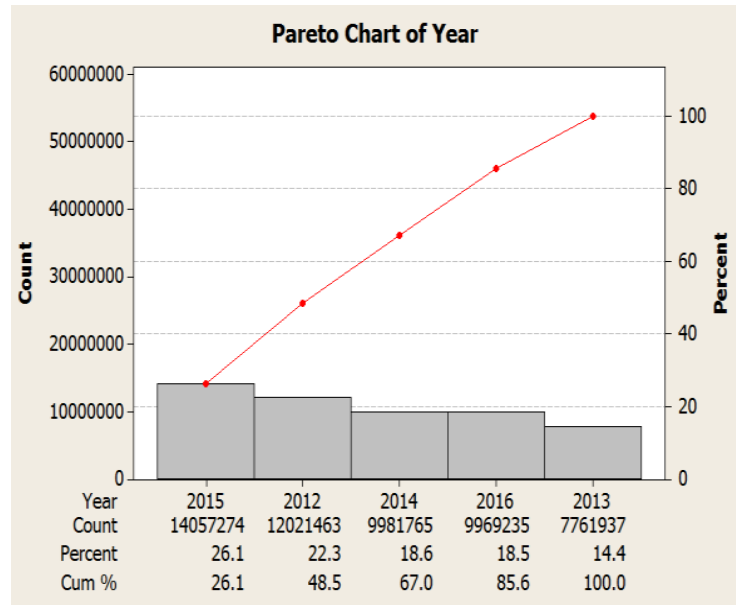

\section{Interpretation}

The Pareto analysis is used to organize data to show what significant factors make up the subject being analyzed. It is interpreted that glass tubes which are imported in the year 2015 have more defects than remaining years. In the year 2013 less number of damaged or defected glass tubes were introduced.

Pareto Analysis for nickel-iron wires

Table 1.6

\begin{tabular}{|l|l|l|l|}
\hline Year & Received Quantity & Accepted \% & Accepted Quantity \\
\hline 2012 & 3817 & 0.9969 & 3805.17 \\
\hline 2013 & 3026 & 0.9956 & 3012.69 \\
\hline 2014 & 3563 & 0.9955 & 3546.97 \\
\hline 2015 & 3964 & 0.9957 & 3946.95 \\
\hline 2016 & 3180 & 0.9961 & 3167.60 \\
\hline
\end{tabular}

Table 1.7

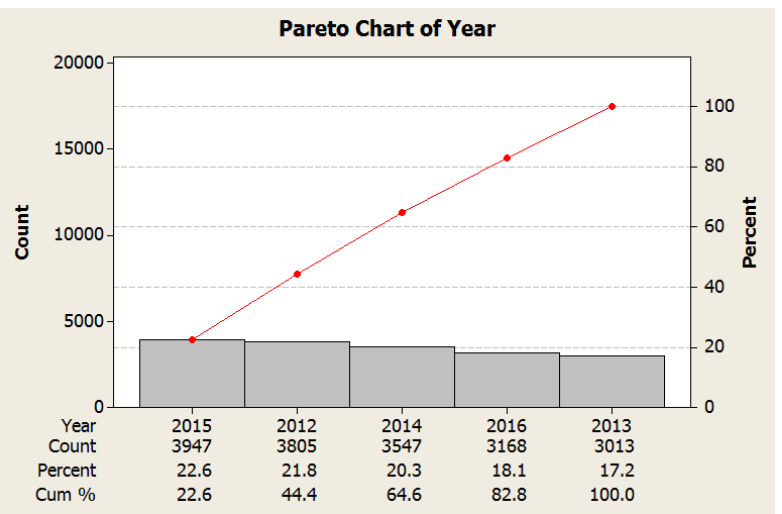

Interpretation

The Pareto analysis is used to organize data to show what significant factors make up the subject being analyzed. It is interpreted that nickel-iron wires which are imported in the year 2015 have more defects than remaining years. In the year 2013 less number of damaged or defected glass tubes were introduced.

Pareto Analysis

Table 1.8

\begin{tabular}{|l|l|l|l|}
\hline Year & Received Quantity & Accepted \% & Accepted Quantity \\
\hline 2012 & 20515 & 0.9988 & 20490.38 \\
\hline 2013 & 18480 & 0.9989 & 18459.67 \\
\hline 2014 & 26678 & & \\
\hline 2015 & 30512 & 0.9991 & 26653.99 \\
\hline 2016 & 29596 & 0.968 & 29535.62 \\
\hline
\end{tabular}

Table 1.9

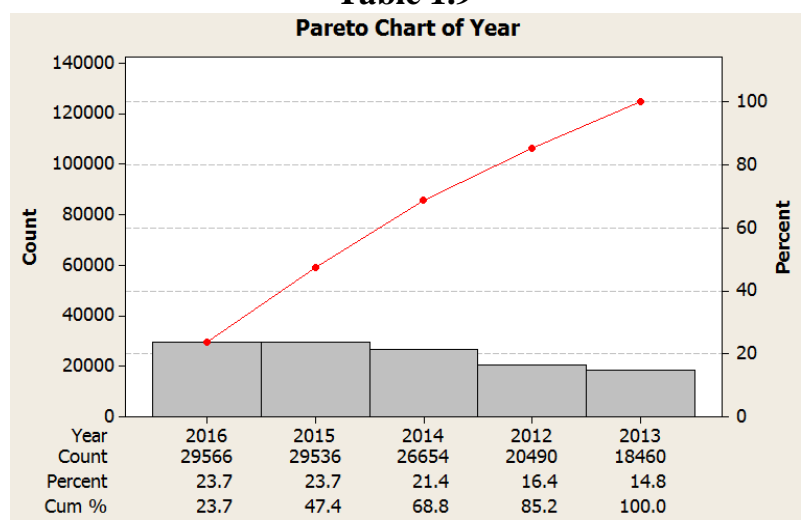

Interpretation

The Pareto analysis is used to organize data to show what significant factors make up the subject being analyzed. It is interpreted that chemical solutions which are imported in the year 2016 have more defects than remaining years. In the year 2013, less quantity of damaged or defected chemical solutions was introduced. 


\section{CONCLUSION}

The study is aimed mainly by understanding the supplier performance evaluation methods, which are carried utilizing importing suppliers of the organization. This study reveals that various factors can influence the supplier performance, and evaluation is done using the delivery time and quality of the purchased materials. This study identifies the multiple reasons that cause the delay in delivery time, such as poor communication between the purchaser and supplier, incomplete shipping procedures, poor capacity management by suppliers. This study concludes that by suggesting the ways to increase ordering the materials more frequently employing economic order quantity (EOQ) in small amounts, by using management software such as Enterprise Resource Planning (ERP) to automate the transmission of information and optimize the network design and improve the supplier performance of the organization.

\section{REFERENCES}

1. Venkatesh.P (2017) An Evaluation of Liquidity and Profitability of Selected Pharmaceutical Companies in India, Journal of Advanced Research in Dynamical \& Control Systems ISSN: 1943-023X, a 07-Special issue on Management Studies.

2. Venkatesh.P (2017) "A Descriptive Analysis of Short Term Solvency and Profitability of Selected Pharmaceutical Companies in India" Journal of Advanced Research in Dynamical \& Control Systems, ISSN: 1943-023X, 07-Special issue on Management Studies.

3. Venkatesh.P (2018) "A Study on Impact of Profit, Earning Per Share And Dividend On Equity Performance On Select Steel Sector Using Discriminant Function Analysis" International Journal of Mechanical and Production Engineering Research and Development (IJMPERD), ISSN (P): 2249-6890; ISSN (E): 2249-8001 Vol. 8, Special Issue 3, PP: 998-1007

4. Venkatesh.P (2018) “A Study On Customer Perception Towards Mugi Ultra Liquid Detergent" International Journal of Mechanical and Production Engineering Research and Development (IJMPERD), ISSN (P): 2249-6890; ISSN (E): 2249-8001 Vol. 8, Special Issue 3, PP: 978-984.

5. Venkatesh.P (2018) "Saving Habit And Investment Preference Of Government School Teachers In Vellore District” International Journal of Mechanical and Production Engineering Research and Development (IJMPERD), ISSN (P): 2249-6890; ISSN (E): 2249-8001 Vol. 8, Special Issue 3, PP: 922-926. 